\title{
Optimization of operational parameters at laboratory scale membrane bioreactor for treatment of high-strength opium alkaloid wastewater: The effect of pretreatment
}

\author{
Ipek ÇELEN-ERDEM ${ }^{1, ~ * i D, ~ G u ̈ l s u ̈ m ~ M e l i k e ~ U ̈ R P E R-B A Y R A M ~}{ }^{2,3}$ (D) , Derya Y. KÖSEO ĞLU- \\ $\dot{I M E R}^{2}$ (D), Ísmail KOYUNCU ${ }^{2,3}$ (D), $\dot{I}_{z z e t} \operatorname{ÖZTÜRK}^{2}$ (iD
}

${ }^{1}$ Environment and Cleaner Production Institute TUBITAK Marmara Research Center Kocaeli / TURKEY

${ }^{2}$ Istanbul Technical University, Civil Enginerring Faculty, Department of Environmental Engineering, Istanbul Technical University Istanbul, 34469, TURKEY

${ }^{3}$ Istanbul Technical University, National Research Center on Membrane Technologies, Istanbul, 34469, TURKEY

\begin{abstract}
Two different membrane treatment scenarios have been applied for treatment of the high strength dark color alkaloid industry wastewater. A membrane bioreactor (MBR) system having separately UF and MF membranes was operated with raw alkaloid wastewater treatment (scenario-A) and anaerobically pre-treated alkaloid wastewater (scenario-B). NF 270, NF 90 and RO (XLE) membranes were used as a polish-ing step at two different recovery ratios of $50 \%$ and $75 \%$ for both scenarios. In scenario-A, the COD re-moval efficiencies for MBR-MF and MBR-UF were found as $86 \pm 9 \%$ and $55 \pm 24 \%$, respectively. At the polishing step, RO performance after scenario-A indicated that the $99.6 \%$ COD and complete color remov-al was achieved. On the other hand, in the scenario-B, the COD removal efficiencies for MBR-MF and MBR-UF were found as $41 \pm 16.4 \%$ and $24 \pm 18.3 \%$, respectively. RO experiments with raw wastewater indi-cated that the $99.6 \% \mathrm{COD}$ and complete color removal were achieved. The most crucial problem during direct MBR operation was found as a foaming problem and prevented by anti-foaming agent which caused an increase in effluent COD concentration and chemical cost. For these reasons, it can be concluded that MBR operation with anaerobically pre-treated was more effective than the other scenario.
\end{abstract}

\section{Article info}

History:

Received: 05.10.2020

Accepted: 08.04.2021

Keywords:

Alkaloid wastewater,

Pretreatment,

Membrane

technologies,

Membrane bioreactor,

Treatment process.

\section{Introduction}

The opiate is a chemical naturally existing in the opium poppy plant, and it is consumed on a big scale by medical sectors and scientific areas. The significant alkaloids are classified as morphine, codeine, thebaine, narcotine, and papaverine [1]. During the production process, the poppy capsules are ground and treated with lime, and the slurry is pressed to extract the liquid that contains the alkaloids. The liquid's $\mathrm{pH}$ is adjusted by adding $\mathrm{Na}_{2} \mathrm{CO}_{3}$ and a filtration process separates the impurities. In the extraction process, the alkaloids are extracted with specific solvents such as toluene and butanol. The morphine is crystallized by adding $\mathrm{NH}_{4} \mathrm{OH}$ and separated from the solution by centrifuges. The used solvents and the water are sent to the distillation column to recover toluene, alcohol groups and the remaining wastewater treated in wastewater treatment plant [2]. The opium is cultivated and processed in a few countries such as India,
Australia, France, Hungary, Spain, Ukraine, Yugoslavia, and Turkey [3]. However, a limited number of researchers have worked on the treatment of alkaloid wastewater until now. Biological and physicochemical treatment studies on the effluent of opium wastewater treatment plant were performed by Kinlı [4], and chemical oxygen demand (COD) removal efficiency reached $70 \%$ in anaerobic treatment process. Also, ozone oxidation was used as the pretreatment technology of the aerobically treated effluents, and the color and COD removal efficiencies of the process were found at $87 \%$ and $30 \%$, respectively. Ozturk et al. [5] also investigated the anaerobic treatment for composite wastewater generated from the process water (extracting from distillation column section) and domestic wastewater of an alkaloid industry. In this study, a full scale Anaerobic Internal Cycling (AIC) reactor was operated with an organic loading rate (OLR) of $5 \mathrm{~kg}$

*Corresponding author. e-mail address: i_celen@yahoo.com

http://dergipark.gov.tr/csj $\quad$ C 2021 Faculty of Science, Sivas Cumhuriyet University 
$\mathrm{COD} / \mathrm{m}^{3}$.day. COD and VFA removal efficiencies were found as 85 and $95 \%$, respectively. The biogas production rate was obtained as $0,1-0,35 \mathrm{~m}^{3}$ $\mathrm{CH}_{4} / \mathrm{COD}_{\text {removed. }}$ The main operational parameters stated in the study were very high salinity and sulphate concentration in composite wastewater. Sakar et al. [6] operated an electrodialysis (EC) process for sulphate removal from the concentrate stream at nanofiltration (NF) membrane process of alkaloid wastewater. They concluded that $99 \%$ of sulfate concentration was retained by membrane and found in concentrate streams of NF90 and NF245 membranes.

Aytimur and Atalay [7] worked on reducing the organic matter in Alkaloid Industry raw wastewater and operated a conventional activated sludge system for biological treatment with $88 \%$ COD removal and also the catalytic wet air oxidation (WAO) process for extra chemical oxidation with the COD removal efficiency of $35 \%$. They concluded that combining these processes is not very effective, and the biological treatment was sufficient for reaching high COD removal efficiency as a single process. Similarly, Kacar et al. [8] investigated the pretreatment of the alkaloid processing wastewater in Turkey by WAO followed by the pressure and temperature on COD removal. The catalyst types in the experiments were $\mathrm{Cu}\left(\mathrm{NO}_{3}\right)_{2}, \mathrm{Co}\left(\mathrm{NO}_{3}\right)_{2}, \mathrm{Ni}\left(\mathrm{NO}_{3}\right)_{2}, \mathrm{FeCl}_{2}$. They reported that above $26 \%$ of COD removal efficiency was obtained in $2 \mathrm{~h}$ of operating time at $150{ }^{\circ} \mathrm{C}, 0.65 \mathrm{MPa}$, and an airflow rate of $1.57 \times 10^{-5} \mathrm{~m}^{3} \mathrm{~s}^{-1}$. Bural et al. [9] investigated the effect of gamma irradiation as pretreatment step on aerobic biological treatment of opium alkaloid wastewater. Two sequencing batch reactors (SBRs) were used as a biological treatment setup in the experiments, one of the reactors was fed with raw wastewater without any irradiation, and the other one was operated with irradiation of $40 \mathrm{kGy}$ at the same raw wastewater. The reactors were gradually fed with increasing COD concentrations because of biomass acclimatization to opium alkaloid wastewater. At the operation with $5000 \mathrm{mg} / \mathrm{L}$ COD concentration, the COD removal efficiencies were $79 \%$ and $73 \%$ for reactors fed with raw and irradiated wastewater, respectively.

Another anaerobic treatment study of alkaloid processing wastewater was presented by Aydin et al. [10]. The treatment study was conducted at an $11.5 \mathrm{~L}$ lab-scale UASB (Upflow Anaerobic Sludge Bed) reactor for 825 days under different hydraulic retention times (HRTs) (0.84-1.62 days) and organic loading rates (OLRs) $\left(3.4-12.25 \mathrm{~kg} \mathrm{COD} / \mathrm{m}^{3}\right.$ day) at $35 \pm 2{ }^{\circ} \mathrm{C}$. The COD removal efficiency slightly decreased with the increase of OLR and decreasing HRT. However, the UASB reactor was operated at high COD removal efficiency varying between $74-88 \%$. They also identified some toxic organic chemicals such as N, Ndimethylaniline, and toluene in the opium wastewaters. These compounds are known to be inhibitory for biological treatment processes. Dereli et al. [11] applied Anaerobic Digestion Model No. 1 (ADM1), developed by the IWA (International Water Association) Task group for Mathematical Modeling on Anaerobic Digestion, for the data obtained by Aydin et al. [10]. The validation results indicated that the calibrated ADM1 could predict the experimental results of effluent $\mathrm{COD}$ and $\mathrm{pH}$ with reasonable accuracy, whereas some discrepancies were observed for methane gas productions. Cengiz et al [1] worked on the hydrothermal gasification of opium alkaloid wastewater and found 95\% COD removal efficiency at $600{ }^{\circ} \mathrm{C}$ in the presence of a catalyst at an amount of $0.375-0.625$ g. Koyuncu [12] carried out membrane treatability studies, and Koyuncu et al. [13] carried out the membrane process and ozonation experiments on the opium alkaloid industry. Lab-scale membrane and ozonation rectors were performed in the experiments. Low-pressure reverse osmosis membranes were used to remove COD, color, and conductivity from biologically pretreated opium alkaloid industry effluents. The influent COD, color, and conductivity were measured as $1900 \mathrm{mg} / \mathrm{L}, 1750 \mathrm{Pt}-\mathrm{Co}$, and 3500 $\mu \mathrm{S} / \mathrm{cm}$. The removal efficiency of COD, color, and conductivity were found greater than $\% 99$. Moreover, they experienced $41 \%$ of COD treatment efficiency with ozonation applied in biologically treated opium alkaloid wastewater in $50 \mathrm{~min}$. The dark-red brownish color of wastewater turned to light yellow after $50 \mathrm{~min}$. of ozonation with $96 \%$ of color removal efficiency. Gencsoy [14] investigated the anaerobic treatment of the opium alkaloid industry. A laboratory scale UASBR was operated at different organic loading rates varying from 3.75 to $10 \mathrm{~kg} \mathrm{COD} / \mathrm{m}^{3}$-day at mesophilic conditions. It was found that anaerobic treatment's COD removal efficiency reached $87 \%$ at UASBR for 5 $\mathrm{kg} \mathrm{COD} / \mathrm{m}^{3}$-day organic loading rate. Besides, the ratio of $\mathrm{CH}_{4}$ content in produced biogas was measured as $72 \%$. From all literature studies, it is concluded that the anaerobic pre-treatment is a very feasible process to upgrade the existing full-scale activated sludge system for the industry.

This study aims to apply two different scenarios to treat the opium alkaloid processing industrial wastewater. The first scenario was the direct application of membrane bioreactor (MBR) for raw alkaloid wastewater treatment without any pretreatment process. At the second scenario, the MBR system was operated after anaerobically pretreated alkaloid wastewater. The polishing step was applied for both 
scenarios using NF and RO membranes. The study's primary purpose is to investigate the effect and importance of the anaerobic pretreatment of highstrength opium alkaloid wastewater before the application of membrane technologies and to compare the results of two scenarios. Opium alkaloid wastewater is very complex wastewater and has high pollutant concentrations. For this reason, different membrane treatment scenarios were proposed in this study to solve this significant industrial wastewater pollution problem. The study's novelty is to evaluate the different operating scenarios with and without pretreatment and build an optimum and sustainable treatment process flow-chart.

\section{Material and Methods}

\subsection{Wastewater characteristics}

The raw wastewater was taken from the opium alkaloid processing plant which located in Afyon Province in Turkey. The characteristics of raw wastewater and the discharge standards of receiving environment at the effluent stream of the wastewater treatment plant are shown in Table 1. All analyses were carried out according to Standard Methods [15].

Table 1. Characteristics of wastewater streams used in the experimental runs

\begin{tabular}{lcc}
\hline Parameters & $\begin{array}{c}\text { Properties } \\
\text { of raw wastewater }\end{array}$ & $\begin{array}{c}\text { Discharge } \\
\text { standards }^{\mathrm{a}}\end{array}$ \\
\hline $\mathrm{pH}$ & $4.7 \pm 0.6$ & $6-12$ \\
Biochemical Oxygen Demand (BOD) (mg/L) & $10151 \pm 3908$ & - \\
Chemical Oxygen Demand (COD) (mg/L) (as soluble) & $32995 . \pm 8811$ & - \\
Total Suspended Solid (SS) (mg/L) & $427.5 \pm 235$ & - \\
Volatile Suspended Solids (VSS) (mg/L) & $426 \pm 217.5$ & - \\
Total Dissolved Solids (TDS) (mg/L) & $41133 \pm 6559$ & 500 \\
Inorganic TDS (mg/L) & $15910 \pm 8584$ & - \\
Conductivity ( $\mu$ s/cm) & $29750 \pm 10111$ & - \\
Volatile fatty acids (VFA) (mg/L) & $5806 \pm 1773$ & - \\
Total Kjeldahl Nitrogen (TKN) (mg/L) & $561 \pm 71$ & 15 \\
Ammonium Nitrogen (NH 4 -N) (mg/L) & $22 \pm 5.6$ & - \\
SO ${ }_{4}^{2-}(\mathrm{mg} / \mathrm{L})$ & $11656 \pm 4087$ & 1700 \\
Total Phosphorus (TP) (mg/L) & $23.8 \pm 6.7$ & - \\
Alkalinity (mg/L CaCO3) & $4504 \pm 1866$ & - \\
Color (Pt-Co) & 2500 & - \\
Particle size, $\mu \mathrm{m}$ & 13.18 & - \\
\hline Wa & &
\end{tabular}

${ }^{a}$ Water Pollution Control Regulations of Turkey

\subsection{Properties of membranes}

Nanofiltration (NF) and reverse osmosis (RO) membranes were provided by Dow/Filmtec and the microfiltration membrane (MF) was purchased from Microdyn Nadir. Table 2 provides some information of the membranes given by the manufacturers. 
Table 2. The technical characteristics of used membranes

\begin{tabular}{lcccc}
\hline Membrane & Manufacturer & $\begin{array}{c}\text { Molecular weight cut-off, } \\
(\mathrm{Da}) / \text { Pore size }(\mu \mathrm{m})\end{array}$ & Material & Flux $\left(\mathrm{L} / \mathrm{m}^{2} . \mathrm{h}\right)$ \\
\hline MP 005 & Microdyn Nadir & $-/ 0.05$ & Polyethersulfone & $>200$ \\
NF 270 & Dow & $\sim 200-400 /-$ & Polyamide & $42-58$ \\
NF 90 & Dow & $\sim 200-400 /-$ & Polyamide & $27-35$ \\
XLE & Dow & $\sim 100 /-$ & Polyamide & $19-24$ \\
\hline
\end{tabular}

\subsection{Experimental set-up}

This study examined the treatment of high-strength dark color opium alkaloid processing industry wastewater and anaerobically pretreated opium alkaloid wastewater effluent with membrane technology. In the experimental system, two parallel laboratory scale membrane bioreactors (MBR) with and without anaerobic pretreatment were used and the volume of each cylindrical MBR was $6 \mathrm{~L}$ with height and internal diameter of $35 \mathrm{~cm}$ and $14 \mathrm{~cm}$, respectively (Fig. 1). MBR was established with microfiltration (MF) and ultrafiltration (UF) membrane modules at submerged mode in the bioreactor in series operation. Monitoring parameters were determined as $\mathrm{pH}$, ORP (Oxidation Reduction Potential), temperature, and dissolved oxygen and were controlled with an online system. Before the treatment, the activated sludge was taken from the return sludge line at the leachate wastewater treatment plant and it was used for inoculation medium.

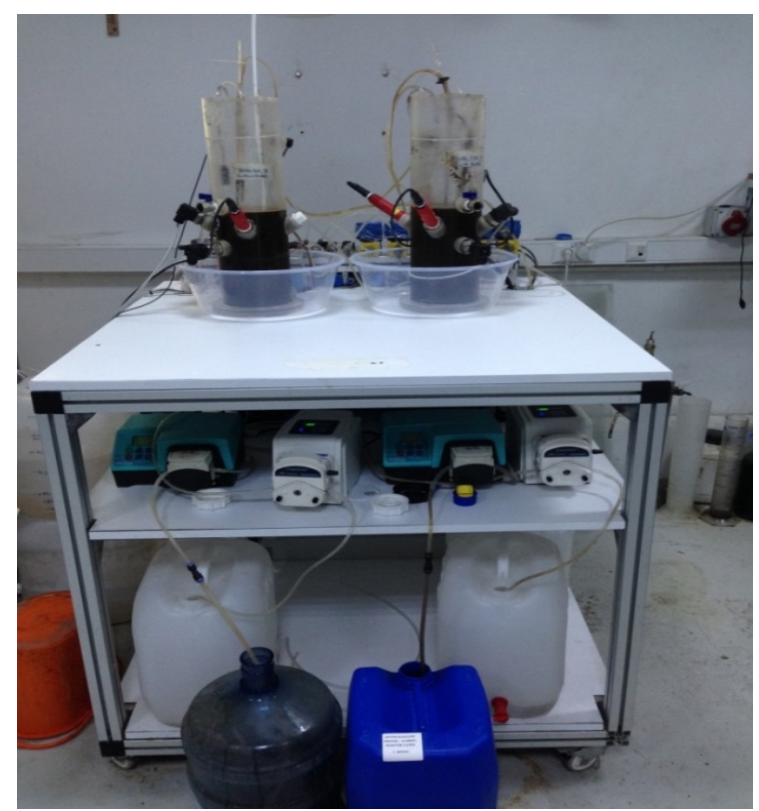

Figure 1. Laboratory scale MBR system
A flow chart of the membrane treatment scenarios is shown in Fig. 2. In the first scenario (Scenario-A) the raw wastewater (Fig 2a) was directly fed to the MBR system and the system was operated at different membrane types (MF and UF, named as Scenario-A1 and Scenario-A2). The MBRs were first operated at step-fed mode with gradually increasing ratios (raw wastewater volume/total volume) in order to acclimatize the biomass to opium alkaloid raw wastewater. After acclimation, the raw wastewater fed to parallel MBR-MF systems for Scenario-A1 and after reaching steady state conditions, UF modules were installed other MBR systems for Scenario-A2. Both MBR systems were tested at the same operating conditions. The effluent streams of MBR-MF and MBR-UF operations were simultaneously filtrated from NF and RO membranes at different recovery ratios for the polishing step. A $300-\mathrm{mL}$ of stirred cell (Sterlitech HP4750, USA) was used for RO and NF filtration. The membrane diameter was $0.049 \mathrm{~m}$ and the effective membrane area was $1.46 \times 10^{-3} \mathrm{~m}^{2}$. The maximum operating pressure for this cell was $69 \times 10^{5} \mathrm{~Pa}$.

In the second scenario (Scenario-B), the raw wastewater was first exposed to anaerobic pretreatment and then MBRs having MF and UF were used for second step biological treatment Scenario-B1 and Scenario-B2, respectively (as seen from Fig 2b). In the last scenario, (Scenario-B3) the anaerobic pretreated wastewater was directly filtrated from the UF membrane. For all the treatment strategies, similar to Scenario-A NF and RO membrane operations were used as a polishing treatment step. 
Table 3. The properties of the anaerobic digester effluent

\begin{tabular}{ll}
\hline Parameters & Value \\
\hline $\mathrm{pH}$ & 8.2 \\
$\begin{array}{l}\text { Soluble chemical oxygen demand } \\
(\mathrm{COD})(\mathrm{mg} / \mathrm{L})\end{array}$ & $2027 \pm 6$ \\
& 83 \\
Suspended Solid (SS) (mg/L) & 15900 \\
Color (PtCo) & 3887 \\
Particle size, $\mu \mathrm{m}$ & 0.032 \\
\hline
\end{tabular}

At the anaerobic treatment phase, a laboratory scale anaerobic digester (W8) was used and the system consists two separate reactors (Armfield Ltd, UK). Anaerobic treatment experiments were carried out over a nine-month periodThe details of this experiment were published by Çelen-Erdem et al. [16]. The effluent stream of reactor was fed to both MBR systems. The characteristics of the anaerobic digester effluent are shown in Table 3.

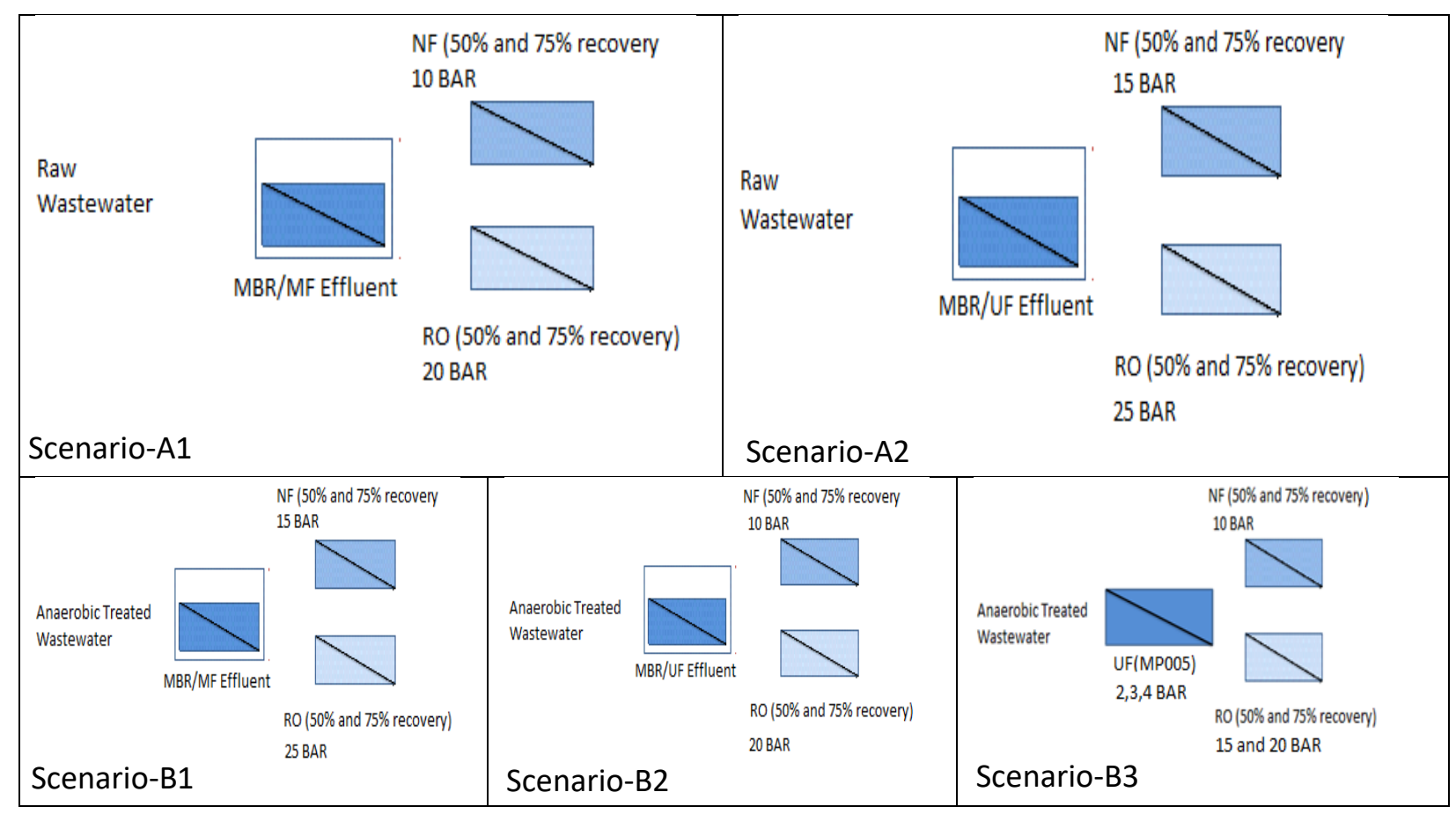

Figure 2. Membrane treatment strategies applied in experimental runs (a) Raw wastewater (b)Anaerobically pretreated wastewater

\section{Results and Discussion}

\subsection{Treatability of raw alkaloid wastewaters with MBR operation (Scenario-A)}

\subsubsection{MBR operation}

In this Scenario-A, the MBR system was fed gradually with raw opium alkaloid wastewater with step-fed mode to acclimatize the biomass. Two different membrane types were used for MBR operation as MF (Scenario-A1) and UF (ScenarioA2). The steady state conditions reached 60 days at MBR-MF and 80 days at MBR-UF, respectively.

The MLSS (Mixed Liquor Suspended Solids) concentration in the MBR reactor was measured at around $15100 \mathrm{mg} / \mathrm{L}$ at the beginning of experiment. After the feeding of raw wastewater with step-fed mode, the MLSS and MLVSS (Mixed Liquor Volatile Suspended Solids) concentrations gradually increased in MBR and the trend is graphically shown in Figure 3a. The average values of MLSS and MLVSS concentrations were measured as $32555 \pm 16$ $\mathrm{mg} / \mathrm{L}, 40347 \pm 16 \mathrm{mg} / \mathrm{L}$ for MBR-MF and $25083 \pm 12$ $\mathrm{mg} / \mathrm{L}, 27164 \pm 11 \mathrm{mg} / \mathrm{L}$ for MBR-UF operations, respectively. The removal efficiency of organic 
matter was evaluated by means of COD concentration removal. The average influent and effluent COD concentrations for MBR-MF were $15136 \pm 89 \mathrm{mg} / \mathrm{L}$ and $1858 \pm 96 \mathrm{mg} / \mathrm{L}$, respectively. However, the average influent and effluent COD concentrations were $35713 \pm 99 \mathrm{mg} / \mathrm{L}$ and $18529 \pm 12 \mathrm{mg} / \mathrm{L}$, respectively for MBR-UF. In this period, the most important operational drawback in MBR was the foaming problem during the experiment. For prevention of this problem, about $0.2-0.5 \mathrm{~mL}$ antifoaming agent was used at everyday but it increased the effluent COD concentration and the COD removal efficiency was affected negatively $[17,18]$. As can be followed from the Figure $3 b$, the COD removal efficiencies for MBR-MF and MBR-UF were found as $86 \pm 9 \%$ and $55 \pm 24 \%$, respectively. Due to the very high load, the sieving effect on the particles improves the turbidity and suspended solids in a very limited amount of suspended solids in the effluents from both MBRs [19,20].

As shown in Figure 3c, for MBR-MF the permeate flux value and daily treated wastewater flow were about $2 \pm 0.9 \mathrm{~L} / \mathrm{m}^{2} \mathrm{~h}$ and $3.5 \pm 1.6 \mathrm{~L} /$ day, respectively. However, when the MBR-UF was used the average the permeate flux value and daily treated wastewater flow were $2 \pm 1.16 \mathrm{~L} / \mathrm{m}^{2} \mathrm{~h}$ and $3.5 \pm 1.96 \mathrm{~L} /$ day, respectively. Color removal was not achieved as can be seen in Figure 3d. The approximate $\mathrm{pH}$ was 7.9 and ORP was $366 \mathrm{mV}$ during the running time. At MBR operation with raw wastewater, it can be said that the flux and flowrate value of UF membrane were greater than that of MF membrane, although the COD values were increasing step by step. COD removal efficiencies of UF membrane were also higher than MF membrane.

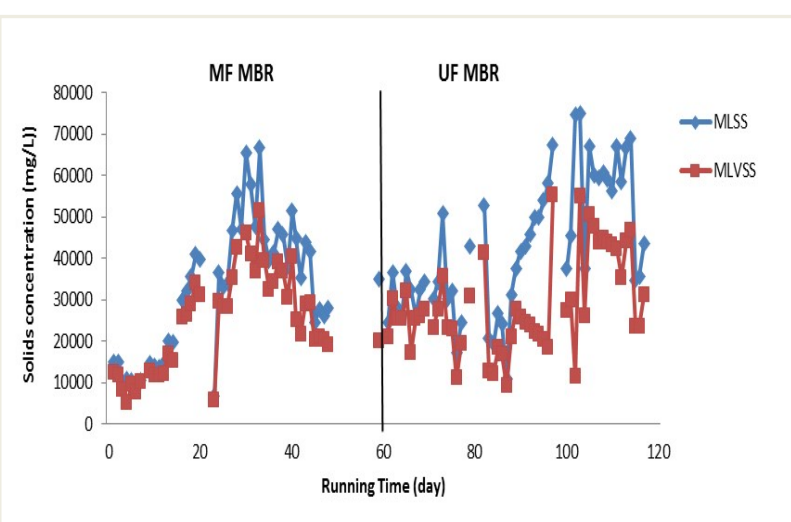

(a)

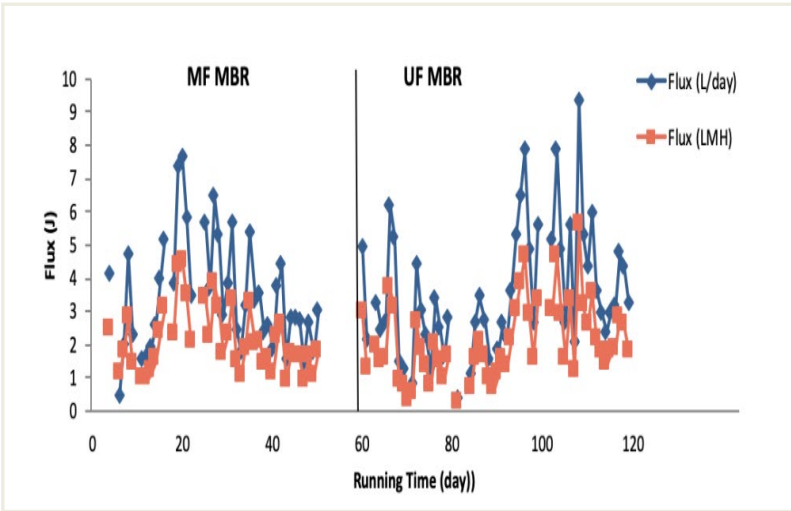

(c)

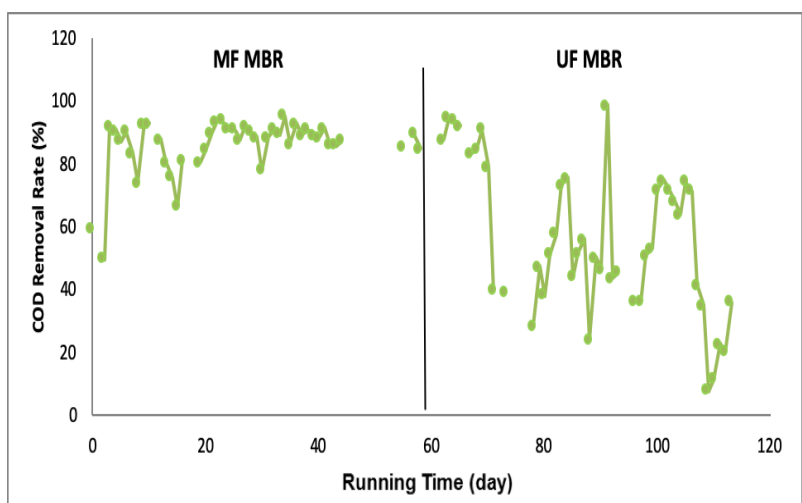

(b)

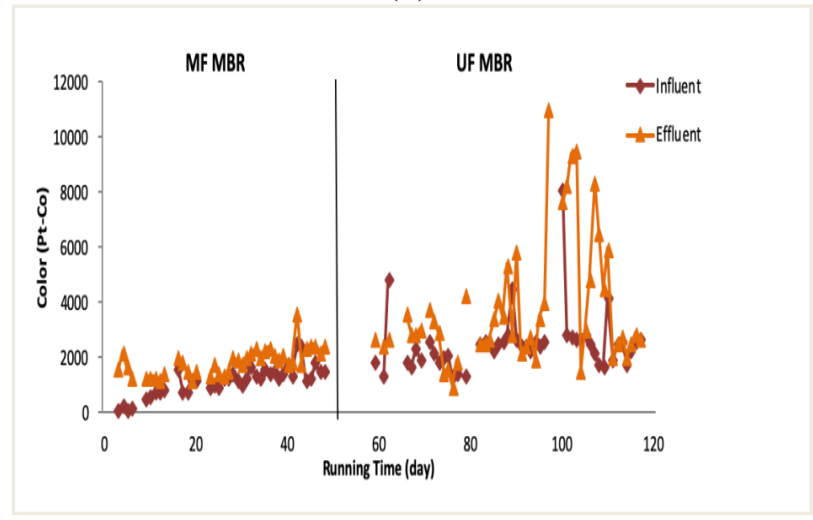

(d)

Figure 3. The graph of parameters during MBR operation with raw alkaloid wastewater (a) MLSS and MLVSS, (b) COD (c) Flux and (d) Color results 


\subsubsection{NF and RO treatment studies}

In Scenario-A, the permeate streams from MBR/MF (scenario-A1) and MBR/UF (scenario-A2) were treated separately by NF (NF270 and NF90 membranes) and RO (XLE membrane) systems at two different recovery ratios $(75 \%$ and $50 \%)$. The NF (NF 270 and NF 90) and RO (XLE) membranes were operated at two recovery ratios of $50 \%$ and $75 \%$. RO experiments with raw wastewater indicated that the $99.6 \%$ COD and complete color removal was achieved. The performance of RO membrane based on the removal efficiency of conductivity, COD, and color was higher than that of NF membrane (Table 4 and 5). In a study by Fazlioglu et al. [21] used industrial wastewater with MBR process and they investigated $\mathrm{NF}$ and $\mathrm{RO}$ membrane and their suitability for agricultural irrigation. They also found RO permeate more suitable for most of the parameters especially high conductivity removal efficiency.

Table 4. NF and RO experiment results of MBR-MF with raw alkaloid wastewater

\begin{tabular}{ccccccccccc}
\hline \multirow{2}{*}{$\begin{array}{c}\text { Membrane } \\
\text { type }\end{array}$} & $\begin{array}{c}\text { Pressure } \\
\text { (bar) }\end{array}$ & $\begin{array}{c}\text { Recovery } \\
\text { Ratio (\%) }\end{array}$ & $\begin{array}{c}\text { Flux } \\
(\mathrm{LMH})\end{array}$ & \multicolumn{2}{c}{$\begin{array}{c}\text { Conductivity } \\
(\mathrm{mS} / \mathrm{cm})\end{array}$} & \multicolumn{2}{c}{$\begin{array}{c}\text { COD } \\
(\mathrm{mg} / \mathrm{L})\end{array}$} & \multicolumn{2}{c}{$\begin{array}{c}\text { Color } \\
\text { (Pt-Co) }\end{array}$} \\
\cline { 6 - 11 } NF270 & 10 & $75 \%$ & 7.55 & 13.3 & 9.45 & 1220 & 300 & 3975 & 238.5 \\
NF270 & 10 & $50 \%$ & 10.8 & 13.3 & 8.72 & 1220 & 402.5 & 3975 & 148 \\
XLE & 15 & $50 \%$ & 6.45 & 13.3 & 1.5 & 1220 & 61.5 & 3975 & 119 \\
XLE & 15 & $75 \%$ & 2.6 & 13.3 & 1.8 & 1220 & 82.5 & 3975 & 108.5 \\
\hline
\end{tabular}

Table 5. NF and RO experiment results of MBR-UF with raw alkaloid wastewater

\begin{tabular}{|c|c|c|c|c|c|c|c|c|c|}
\hline \multirow{2}{*}{$\begin{array}{l}\text { Membrane } \\
\text { type }\end{array}$} & \multirow{2}{*}{$\begin{array}{c}\text { Pressure } \\
\text { (bar) }\end{array}$} & \multirow{2}{*}{$\begin{array}{l}\text { Recovery } \\
\text { Ratio (\%) }\end{array}$} & \multirow{2}{*}{$\begin{array}{c}\text { Flux } \\
(\text { LMH) }\end{array}$} & \multicolumn{2}{|c|}{$\begin{array}{l}\text { Conductivity } \\
(\mathrm{mS} / \mathrm{cm})\end{array}$} & \multicolumn{2}{|c|}{$\begin{array}{l}\mathrm{COD} \\
(\mathrm{mg} / \mathrm{L})\end{array}$} & \multicolumn{2}{|c|}{$\begin{array}{l}\text { Color } \\
\text { (Pt-Co) }\end{array}$} \\
\hline & & & & Influent & Effluent & Influent & Effluent & Influent & Effluent \\
\hline \multirow{2}{*}{$\begin{array}{l}\text { NF270 } \\
\text { NF270 }\end{array}$} & 15 & $50 \%$ & 8.6 & 40.6 & 11.5 & 18500 & 9500 & 4625 & 498 \\
\hline & 15 & $75 \%$ & 2.7 & 40.6 & 19.6 & 18500 & 1925 & 4625 & 461.5 \\
\hline \multirow{2}{*}{$\begin{array}{l}\text { NF90 } \\
\text { NF90 }\end{array}$} & 30 & $50 \%$ & 2.1 & 40.6 & 14 & 18500 & 1055 & 4625 & 629 \\
\hline & 30 & $75 \%$ & 2.2 & 40.6 & 15.8 & 18500 & 1400 & 4625 & 1000 \\
\hline XLE & 25 & $50 \%$ & 2.8 & 40.6 & 3.8 & 18500 & 244 & 4625 & 104.5 \\
\hline XLE & 25 & $75 \%$ & 2.6 & 40.6 & 10.6 & 18500 & 322 & 4625 & 96 \\
\hline
\end{tabular}

\subsection{Treatment of anaerobically pretreated wastewater in MBR (Scenario-B)}

\subsubsection{MBR operation}

In Scenario-B, the raw wastewater was firstly exposed to anaerobic treatment and then the effluent stream of anaerobic digester was fed to MBR-MF for 60 days and MBR-UF for 60 days. During the experiments, two different membrane types were used for MBR operation of anaerobic treated effluent as MF (Scenario-B1) and UF (Scenario-B2). In Fig.4a, the change of MLSS concentration at MBR with anaerobic pretreated wastewater is given and the MLSS concentration was measured about 15900 $\mathrm{mg} / \mathrm{L}$ at the beginning of the experiment. The average values of the MLSS become $10461 \pm 52 \mathrm{mg} / \mathrm{L}$ and $16454 \pm 76 \mathrm{mg} / \mathrm{L}$ in the MBR-MF and MBR-UF 
reactors, respectively. The average values of MLSS and MLVSS concentrations were measured as $10461 \pm 52 \mathrm{mg} / \mathrm{L}, 7326 \pm 31$ for MBR-MF and $16454 \pm 76,7565 \pm 27 \mathrm{mg} / \mathrm{L}$ for MBR-UF operations, respectively. The average influent and effluent COD concentrations for MBR-MF were $2120 \pm 96 \mathrm{mg} / \mathrm{L}$ and $1401 \pm 46 \mathrm{mg} / \mathrm{L}$, respectively. However, the average influent and effluent COD concentrations for MBRUF were $2847 \pm 12 \mathrm{mg} / \mathrm{L}$ and $2466 \pm 99 \mathrm{mg} / \mathrm{L}$, respectively. As can be followed from the Figure $4 \mathrm{~b}$, the COD removal efficiencies for MBR-MF and MBR-UF were found as $41 \pm 16 \%$ and $24 \pm 18 \%$,

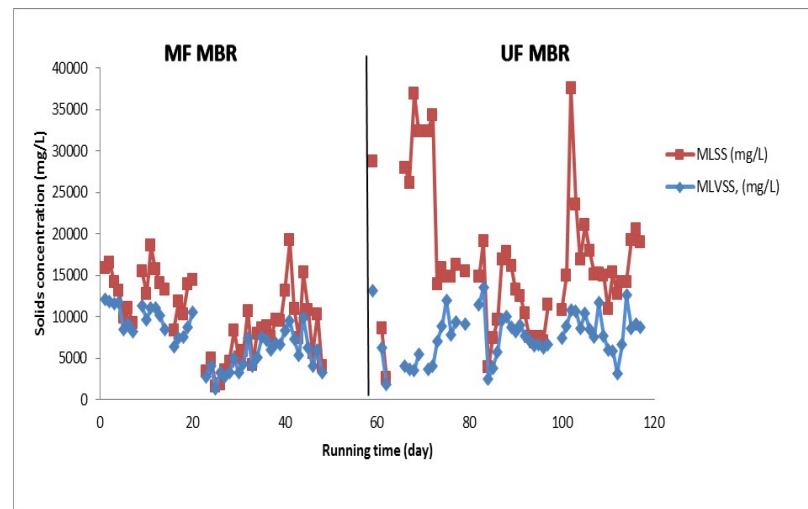

(a)

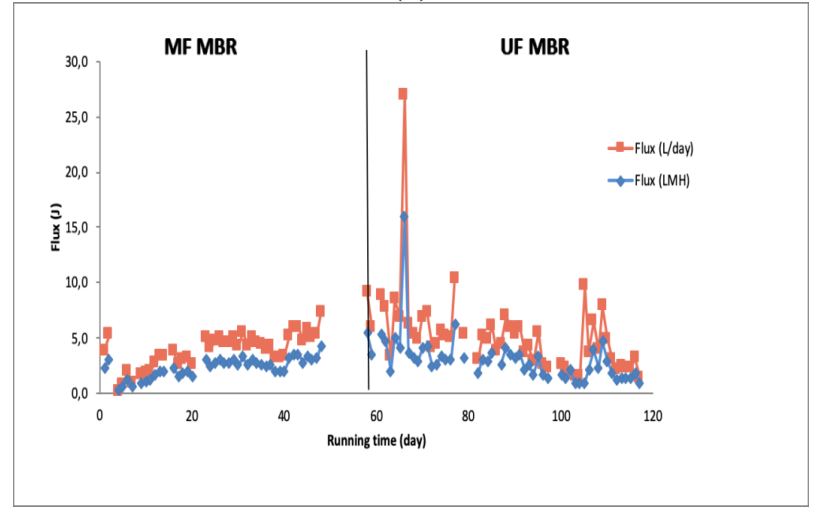

(c) respectively. As shown in Figure 4c, for MBR-MF the permeate flux value and daily treated wastewater flow were about $2.4 \pm 0.9 \mathrm{~L} / \mathrm{m} 2 \mathrm{~h}$ and $4 \pm 1.7 \mathrm{~L} /$ day, respectively. However, when the MBR-UF was used the average the permeate flux value and daily treated wastewater flow were $3 \pm 2.2 \mathrm{~L} / \mathrm{m} 2 \mathrm{~h}$ and $5 \pm 3.7 \mathrm{~L} /$ day, respectively. Color removal was not achieved as can be seen in Figure 4d. During the reactor performance HRT was approximately 1.25 days, $\mathrm{pH}$ and ORP were 9.0 and $366 \mathrm{mV}$ respectively. Also, no sludge was discarded from the system.

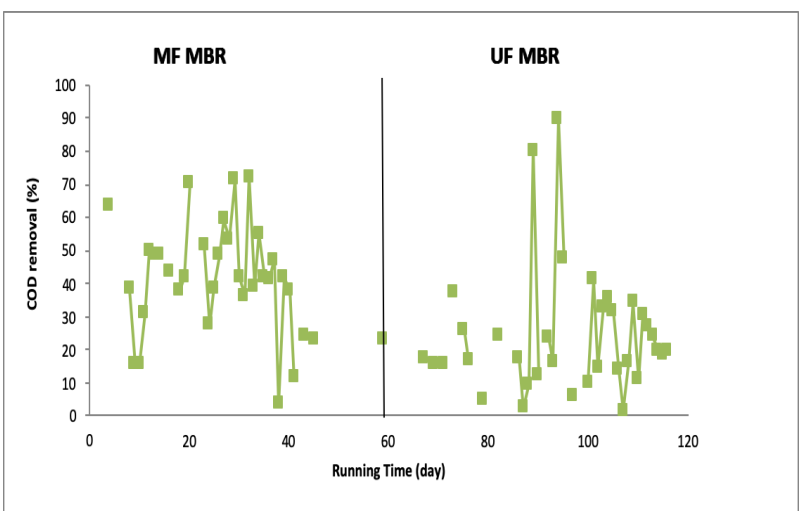

(b)

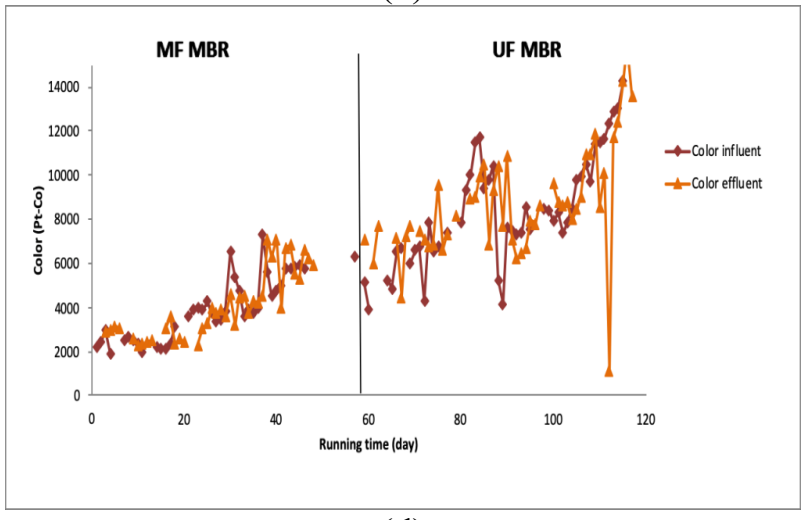

(d)

Figure 4. The graph of parameters during MBR operation with anaerobically pretreated alkaloid wastewater (a) MLSS and MLVSS, (b) COD (c) Flux, and (d) Color results.

\subsubsection{NF and RO treatment studies}

As shown in Figure 2b, two different types of membrane treatment strategies were applied to the anaerobically pretreated opium alkaloid wastewater. The effluents from MBR/MF (scenario-B1) and $\mathrm{MBR} / \mathrm{UF}$ (scenario-B2) were treated by NF and RO units. Moreover, low COD removal of anaerobically pretreated opium alkaloid wastewater was determined in the MBR. Therefore, the NF and RO membrane applications with UF pretreatment were used in order to increase the removal rates (ScenarioB3). The NF (NF 270) and the RO (XLE) membranes were operated at the recovery ratio of $50-75 \%$. RO experiments with raw wastewater indicated that the 99.6\% COD and complete color removal were achieved. The performance of RO membrane based on the removal efficiency of conductivity, COD, and color was higher than that of NF membrane (Table 6 and 7). 
Table 6. NF and RO experiment results of MBR-MF with anaerobically pretreated alkaloid wastewater

\begin{tabular}{cccccccccc}
\hline \multirow{2}{*}{$\begin{array}{c}\text { Membrane } \\
\text { type }\end{array}$} & $\begin{array}{c}\text { Pressure } \\
\text { (bar) }\end{array}$ & $\begin{array}{c}\text { Recovery } \\
\text { Ratio (\%) }\end{array}$ & $\begin{array}{c}\text { Flux } \\
(\mathrm{LMH})\end{array}$ & $\begin{array}{c}\text { Conductivity } \\
(\mathrm{mS} / \mathrm{cm})\end{array}$ & \multicolumn{2}{c}{$\begin{array}{c}\text { COD } \\
(\mathrm{mg} / \mathrm{L})\end{array}$} & \multicolumn{2}{c}{$\begin{array}{c}\text { Color } \\
\text { (Pt-Co) }\end{array}$} \\
\hline NF270 & 10 & 75 & 10.4 & 20.2 & 17.3 & 3700 & 1160 & 6925 & 369 \\
NF270 & 10 & 50 & 23.0 & 20.2 & 15.6 & 3700 & 120 & 6925 & 1010 \\
XLE & 20 & 50 & 3.4 & 20.2 & 7.1 & 3700 & 40 & 6925 & 149 \\
XLE & 20 & 75 & 3.2 & 20.2 & 14.9 & 3700 & 98 & 6925 & 170 \\
\hline
\end{tabular}

Table 7. NF and RO experiment results of MBR-UF with anaerobically pretreated alkaloid wastewater

\begin{tabular}{|c|c|c|c|c|c|c|c|c|c|}
\hline \multirow{2}{*}{$\begin{array}{c}\text { Membrane } \\
\text { type }\end{array}$} & \multirow{2}{*}{$\begin{array}{c}\text { Pressure } \\
\text { (bar) }\end{array}$} & \multirow{2}{*}{$\begin{array}{l}\text { Recovery } \\
\text { Ratio (\%) }\end{array}$} & \multirow{2}{*}{$\begin{array}{c}\text { Flux } \\
(\mathrm{LMH})\end{array}$} & \multicolumn{2}{|c|}{$\begin{array}{l}\text { Conductivity } \\
(\mathrm{mS} / \mathrm{cm})\end{array}$} & \multicolumn{2}{|c|}{$\begin{array}{c}\text { COD } \\
(\mathrm{mg} / \mathrm{L})\end{array}$} & \multicolumn{2}{|c|}{$\begin{array}{l}\text { Color } \\
\text { (Pt-Co) }\end{array}$} \\
\hline & & & & Influent & Effluent & Influent & Effluent & Influent & Effluent \\
\hline \multirow{2}{*}{$\begin{array}{l}\text { UF-MP005 } \\
\text { UF-MP005 }\end{array}$} & 2 & 100 & 8.6 & 13.5 & 13.3 & 3140 & 1680 & 5280 & 2800 \\
\hline & 3 & 100 & 8.6 & 13.5 & 13.3 & 3140 & 1680 & 5280 & 2800 \\
\hline \multirow{2}{*}{$\begin{array}{l}\text { UF-MP005 } \\
\text { NF270 }\end{array}$} & 4 & 100 & 11.3 & 13.5 & 13.3 & 3140 & 1680 & 5280 & 2800 \\
\hline & 10 & 75 & 10.5 & 13.3 & 10.6 & 1680 & 306 & 2800 & 336 \\
\hline NF270 & 10 & 50 & 14.7 & 13.3 & 9.5 & 1680 & 226 & 2800 & 364 \\
\hline XLE & 15 & 50 & 2.9 & 13.3 & 2.9 & 1680 & 128 & 2800 & 107 \\
\hline XLE & 20 & 75 & 3.5 & 13.3 & 2.0 & 1680 & 105 & 2800 & 84 \\
\hline XLE & 20 & 50 & 10.4 & 13.3 & 1.0 & 1680 & 51 & 2800 & 70 \\
\hline
\end{tabular}

Table 8. NF and RO experiment results of UF with anaerobically pretreated alkaloid wastewater

\begin{tabular}{cccccccccc}
\hline $\begin{array}{c}\text { Membrane } \\
\text { type }\end{array}$ & $\begin{array}{c}\text { Pressure } \\
\text { (bar) }\end{array}$ & $\begin{array}{c}\text { Recovery } \\
\text { Ratio (\%) }\end{array}$ & $\begin{array}{c}\text { Flux } \\
(\mathrm{LMH})\end{array}$ & \multicolumn{2}{c}{$\begin{array}{c}\text { Conductivity } \\
(\mathrm{mS} / \mathrm{cm})\end{array}$} & \multicolumn{2}{c}{ COD (mg/L) } & \multicolumn{2}{c}{$\begin{array}{c}\text { Color } \\
\text { (Pt-Co) }\end{array}$} \\
\hline \multirow{2}{*}{ Influent } & Effluent & Influent & Effluent & Influent & Effluent \\
\hline UF-MP005 & 2 & 100 & 8.6 & 13.5 & 13.3 & 3140 & 1680 & 5280 & 2800 \\
& 3 & 100 & 8.8 & 13.5 & 13.3 & 3140 & 1680 & 5280 & 2800 \\
NF270 & 10 & 75 & 10.5 & 13.3 & 10.6 & 1680 & 306 & 2800 & 336 \\
XLE & 10 & 50 & 14.7 & 13.3 & 9.5 & 1680 & 226 & 2800 & 364 \\
XLE & 15 & 50 & 2.9 & 13.3 & 2.9 & 1680 & 128 & 2800 & 107 \\
XLE & 20 & 75 & 3.5 & 13.3 & 2.0 & 1680 & 105 & 2800 & 84 \\
\hline
\end{tabular}


At the last part of the experiments, UF-MP005 was applied to the effluents of anaerobically treated opium alkaloid processing effluent as pretreatment (Figure 2b). Experimental results indicated that COD, color, and conductivity removals of $46 \%, 47 \%$, and $0 \%$, respectively, were possible at a pressure of 2,3 , 4 bar as shown in Table 8. The NF (NF 270) and reverse osmosis were applied to the UF pretreated effluent. It demonstrated that the pretreatment before NF and XLE is necessary to obtain high conductivity, $\mathrm{COD}$ and color removal.

COD removal of anaerobically pretreated opium alkaloid wastewater was very low in the MBR treatment experiments. However, when NF membrane application with UF pretreatment option was applied, $82 \%$ COD and $88 \%$ color removal were obtained at $75 \%$ recovery. The removal efficiencies of COD and color were as 94\% and 97\%, respectively, were achieved for NF runs with UF pretreatment.

\subsection{Performance evaluation of all scenarios}

To describe results of experiments, performance of all scenarios was compared in terms of flux, COD and conductivity rejections. As shown in Table 9, permeate values for COD, color and conductivity did not change significantly for the XLE-RO membrane with $75 \%$ recovery ratio. However, anaerobic pretreatment strongly influenced the solute rejections by NF and RO, probably due to lower contact time to solutes with membrane surface because the flux was nearly doubled than raw waste water system. It was seen that although most of the parameters make RO permeate more suitable than NF except flux.

Table 9. Comparison of permeate qualities all scenarios.

\begin{tabular}{|c|c|c|c|c|c|c|c|}
\hline \multirow{4}{*}{ Type } & \multirow{4}{*}{ Parameter } & \multirow{4}{*}{ Units } & \multicolumn{5}{|c|}{ Permeates } \\
\hline & & & \multirow{2}{*}{\multicolumn{3}{|c|}{$\begin{array}{r}50 \% \text { Recovery Ratio } \\
\text { XLE }\end{array}$}} & \multirow{2}{*}{\multicolumn{2}{|c|}{$75 \%$ Recovery Ratio }} \\
\hline & & & & & & & \\
\hline & & & NF 270 & 15 bar & 20 bar & NF 270 & XLE \\
\hline \multirow{4}{*}{$\begin{array}{c}\text { Raw Waste Water }+ \\
\text { MBR MF } \\
\text { (Scenario-A1) }\end{array}$} & Flux & $\mathrm{LMH}$ & 10.8 & 6.45 & & 7.55 & 2.6 \\
\hline & COD & $\mathrm{mg} / \mathrm{L}$ & 402.5 & 61.5 & & 300 & 82.5 \\
\hline & Color & $\mathrm{Pt}-\mathrm{Co}$ & 148 & 119 & & 238,5 & 108,5 \\
\hline & Conductivity & $\mathrm{mS} / \mathrm{cm}$ & 8.72 & 1.5 & & 9.45 & 1.8 \\
\hline \multirow{4}{*}{$\begin{array}{c}\text { Raw Waste Water + } \\
\text { MBR UF } \\
\text { (Scenario- A2) }\end{array}$} & Flux & $\mathrm{LMH}$ & 8.6 & & 2.8 & 2.7 & 2.6 \\
\hline & COD & $\mathrm{mg} / \mathrm{L}$ & 9500 & & 244 & 1925 & 322 \\
\hline & Color & Pt-Co & 498 & & 104,5 & 461.5 & 96 \\
\hline & Conductivity & $\mathrm{mS} / \mathrm{cm}$ & 11.5 & & 3.8 & 19.6 & 10.6 \\
\hline \multirow{4}{*}{$\begin{array}{c}\text { Anaerobically } \\
\text { Pretreated Wastewater } \\
\text { + MBR MF } \\
\text { (Scenario-B1) }\end{array}$} & Flux & $\mathrm{LMH}$ & 23 & & 3.4 & 10.4 & 3.2 \\
\hline & COD & $\mathrm{mg} / \mathrm{L}$ & 120 & & 40 & 1160 & 98 \\
\hline & Color & $\mathrm{Pt}-\mathrm{Co}$ & 1010 & & 149 & 369 & 170 \\
\hline & Conductivity & $\mathrm{mS} / \mathrm{cm}$ & 15.6 & & 7.1 & 17.3 & 14.9 \\
\hline \multirow{4}{*}{$\begin{array}{c}\text { Anaerobically } \\
\text { Pretreated Wastewater } \\
+ \text { MBR UF (Scenario- } \\
\text { B2) }\end{array}$} & Flux & $\mathrm{LMH}$ & 14.7 & 2.9 & 3.5 & 10.5 & 3.5 \\
\hline & COD & $\mathrm{mg} / \mathrm{L}$ & 226 & 128 & 51 & 306 & 105 \\
\hline & Color & $\mathrm{Pt}-\mathrm{Co}$ & 364 & 107 & 70 & 336 & 84 \\
\hline & Conductivity & $\mathrm{mS} / \mathrm{cm}$ & 9.5 & 2.9 & 1 & 10.6 & 2 \\
\hline \multirow{4}{*}{$\begin{array}{c}\text { Anaerobically } \\
\text { Pretreated Wastewater } \\
+ \text { UF (Scenario-B3) }\end{array}$} & Flux & LMH & 14.7 & 2.9 & 10.4 & 10.5 & 3.5 \\
\hline & COD & $\mathrm{mg} / \mathrm{L}$ & 226 & 128 & 51 & 206 & 105 \\
\hline & Color & $\mathrm{Pt}-\mathrm{Co}$ & 364 & 107 & 70 & 336 & 84 \\
\hline & Conductivity & $\mathrm{mS} / \mathrm{cm}$ & 9.5 & 2.9 & 1 & 10.6 & 2 \\
\hline
\end{tabular}




\section{Results and Discussion}

In this study, the treatment of opium alkaloid wastewater was studied with 5 different scenarios. There is a limited number of studies investigating treatment of opium alkoloid wastewater in the literature. Table 10 summarizes the key performance parameters reported in the literature([12] and [22]) for different operations. The usage of NF membrane with MBR system enhanced the NF performance.

The results can be summarized as follows.

(1) The high COD concentration of the wastewater in the MBR experiments caused severe problems such as foaming problem, the chemical usage to prevent foaming. In order to prevent those problems, the wastewater was anaerobically pretreated.
(2) $99.6 \%$ COD and complete color removal were achieved with the RO experiments with alkaloid wastewater.

(3) Very low COD removal of anaerobically pretreated opium alkaloid wastewater was ob-tained in the MBR treatment experiments. The best treatment scenario for the anaerobi-cally pretreated opium alkaloid wastewater was using RO unit following MBR/UF.

(4) COD removal of concentrated opium alkaloid wastewater was $46 \%$ in the MBR system. However, when the NF and RO membrane applications were applied, the COD removals were increased to $94 \%$ and $99.6 \%$, respectively.

(5) For both concentrated and anaerobically pretreated opium alkaloid wastewater treatment scenarios, permeate flux value was increased with NF application.

Table 10. Comparison of the treatment performance of Opium Alkoloid Wastewater with this study.

\begin{tabular}{|c|c|c|c|c|c|c|c|c|c|}
\hline Pretreatment & $\begin{array}{l}\text { Membrane } \\
\text { Systems }\end{array}$ & $\begin{array}{l}\text { Advanced } \\
\text { Treatment }\end{array}$ & $\begin{array}{l}\text { Operation } \\
\text { Parameter }\end{array}$ & $\begin{array}{c}\text { Flux } \\
(\mathrm{LMH})\end{array}$ & $\begin{array}{c}\text { COD } \\
\text { Removal } \\
(\%)\end{array}$ & $\begin{array}{c}\text { Conductivity } \\
\text { Removal } \\
(\%)\end{array}$ & $\begin{array}{c}\text { Color } \\
\text { Removal } \\
(\%)\end{array}$ & Scale & References \\
\hline \multirow{5}{*}{$\begin{array}{l}\text { Anaerobic } \\
\text { Treatment }\end{array}$} & \multirow{2}{*}{ MBR MF } & NF 270 & 10 bar, \% 50 RR & 23 & 97 & 23 & 85.4 & Laboratory & \multirow{8}{*}{ This study } \\
\hline & & RO (XLE) & 20 bar, $\% 50$ RR & 3.4 & $>98$ & 65 & 97.5 & Laboratory & \\
\hline & \multirow{2}{*}{ MBR UF } & NF 270 & 10 bar, \% 50 RR & 14.7 & 86.5 & 28. Haz & 87 & Laboratory & \\
\hline & & RO (XLE) & 20 bar, $\% 50$ RR & 10.4 & 97 & 92.4 & 97.5 & Laboratory & \\
\hline & UF & RO (XLE) & 20 bar, $\% 50$ RR & 10.4 & 97 & 92.5 & 97.5 & Laboratory & \\
\hline \multirow{3}{*}{ - } & \multirow{2}{*}{ MBR MF } & NF 270 & 10 bar, \% 50 RR & 10.8 & 67 & 34 & 96 & Laboratory & \\
\hline & & RO (XLE) & 15 bar, \%50 RR & 6.45 & 93 & 95 & 97 & Laboratory & \\
\hline & MBR UF & RO (XLE) & 25 bar, \% $50 \mathrm{RR}$ & 2.8 & $>98$ & 90.6 & 97.7 & Laboratory & \\
\hline $\begin{array}{c}\text { 2-stage Aerobic } \\
\text { Treatment }\end{array}$ & MBR & $\begin{array}{l}\text { NF } 90+ \\
\text { NF } 270\end{array}$ & 30 bar, $\% 75$ RR & 15 & 95 & 88 & $>98$ & Pilot & \multirow[t]{2}{*}[12]{} \\
\hline \multirow{3}{*}{$\begin{array}{c}\text { 2-stage Aerobic } \\
\text { Treatment }\end{array}$} & UF & NF & 24 bar, $\% 70$ RR & 70 & $>97$ & 94 & $>99$ & Laboratory & \\
\hline & & $\mathrm{NF}$ & 18 bar, \% $70 \mathrm{RR}$ & 12 & 97 & $>98$ & $>99$ & Pilot & \multirow[b]{3}{*}[22]{} \\
\hline & UF & RO & 25 bar & 16 & 98 & 99 & $>99$ & Laboratory & \\
\hline $\begin{array}{c}\text { 2-stage Aerobic } \\
\text { Treatment }+ \\
\text { Anaerobic } \\
\text { Treatment } \\
\text { Anaerobic } \\
\text { Pretreated }\end{array}$ & & $\mathrm{NF}$ & 24 bar & 33 & 95 & 88 & $>98$ & Laboratory & \\
\hline
\end{tabular}

\section{Acknowledgements}

We wish to express our appreciation to the administrative and the technical staff of TMO for the financial support and cooperation during this research project.

\section{Conflicts of Interest}

The authors state that did not have conflict of interests 


\section{Abbreviations}

\begin{tabular}{|c|l|c|l|}
\hline AIC & Anaerobic Internal Cycling & MLVSS & Mixed Liquor Volatile Suspended Solids \\
\hline BOD & Biological Oxygen Demand & NF & Nanofiltration \\
\hline COD & Chemical Oxygen Demand & OLRs & Organic Loading Rates \\
\hline EC & Electrodialysis & ORP & Oxidation Reduction Potential \\
\hline HRTs & Hydraulic Retention Times & RO & Reverse Osmosis \\
\hline IWA & International Water Association & UASB & Upflow Anaerobic Sludge Bed) \\
\hline MBR & Membrane Bioreactor & UF & Ultrafiltration \\
\hline MF & Microfiltration & VFA & Volatile Fatty Acids \\
\hline MLSS & Mixed Liquor Suspended Solids & Wet Air Oxidation \\
\hline
\end{tabular}

\section{Conflicts of Interest}

The authors state that did not have conflict of interests.

\section{References}

[1] Cengiz N.Ü., Sağlam M., Yüksel M., Ballice L., Treatment of high-strength opium alkaloid wastewater using hydrothermal gasification, $J$. Supercrit. Fluids, 130 (2017) 301-310.

[2] Sevimli M.F., Aydın A.F., Sarikaya H.Z., Öztürk İ., Characterization and treatment of effluent from opium alkaloid processing wastewater, Water Sci. Technol., 40 (1999) 2330.

[3] Yaniv Z., Dudai N., Medicinal and aromatic plants of the middle-east, Netherlands: Springer, (2014).

[4] Kinli H., The report of treatability studies of biological wastewater treatment plant effluent of TMO Opium Alkaloids Plant, Marmara Res. Center, TUBITAK, Gebze, Türkiye, (1994).

[5] Ozturk I., Aydin A.F., Koyuncu I., Technical Evaluation Report for Upgrading of Bolvadin Alkaloid Industry Wastewater Treatment Plant, Istanbul Tech. Univ., Istanbul, (2008).
[6] Sakar H., Balcik Canbolat C., Karagunduz A., Keskinler B., Sulfate removal from nanofiltration concentrate of alkaloid wastewater by electrodialysis, Desalin. Water Treat., 57 (2016) 21003-21014.

[7] Aytimur G., Atalay S., Treatment of an alkaloid industry wastewater by biological oxidation and/or chemical oxidation, Energy Sources, 26 (2004) 661-670.

[8] Kaçar Y., Alpay E., Ceylan V.K., Pretreatment of Afyon alcaloide factory's wastewater by wet air oxidation (WAO), Water Res., 37 (2003) 1170-1176.

[9] Bural C.B., Demirer G.N., Kantoglu O., Dilek F.B., Treatment of opium alkaloid containing wastewater in sequencing batch reactor (SBR) Effect of gamma irradiation, Radiat. Phys. Chem., 79 (2010) 519-526.

[10] Aydin A.F., Ersahin M.E., Dereli R.K., Sarikaya H.Z., Ozturk I., Long-term anaerobic treatability studies on opium alkaloids industry effluents, $J$. Environ. Sci. Heal. Part A., 45 (2010) 192-200.

[11] Dereli R.K., Ersahin M.E., Ozgun H., Ozturk I., Aydin A.F., Applicability of Anaerobic Digestion Model No. 1 (ADM1) for a specific industrial wastewater: Opium alkaloid effluents, Chem. Eng. J., 165 (2010) 89-94. 
[12] Koyuncu I., An advanced treatment of highstrength opium alkaloid processing industry wastewaters with membrane technology: Pretreatment, fouling and retention characteristics of membranes, Desalination, 155 (2003) 265-275.

[13] Koyuncu I., Sevimli M.F., Ozturk I., Aydin A.F., Application of membrane and ozonation technologies to remove color from agro-industry effluents, Water Sci. Technol., 43 (2001) 233241.

[14] Gençsoy E.B., Afyon Alkaloidleri Endüstrisi Atıksularının Anaerobik Arıtılması, M.Sc thesis., İstanbul Technical University, (2003).

[15] A. American Public Health Association, Standard methods for the examination of water and wastewater, American public health association Washington DC, (1995).

[16] Çelen Erdem İ., Türker M., Çiftçi G., Öztürk İ., Çiftçi T., Afyon Alkoloidleri Endüstrisi Atiksularinin Anaerobik Proseslerle Aritilabilirliği, Mühendislik Bilim. ve Tasartm Derg., 6(3) (2018) 479-486.

[17] Bouhabila E.H., Ben Aïm R., Buisson H., Microfiltration of activated sludge using submerged membrane with air bubbling (application to wastewater treatment), Desalination, 118 (1998) 315-322.

[18] Benitez J., Rodríguez A., Malaver R., Stabilization and dewatering of wastewater using hollow fiber membranes, Water Res., 29 (1995) 2281-2286.

[19] Arévalo J., Ruiz L.M., Parada-Albarracín J.A., González-Pérez D.M., Pérez J., Moreno B., Gómez M.A., Wastewater reuse after treatment by MBR. Microfiltration or ultrafiltration? Desalination, 299 (2012) 22-27.

[20] Domínguez L., Cases V., Birek C., Rodríguez M., Prats D., Influence of organic loading rate on the performance of ultrafiltration and microfiltration membrane bioreactors at high sludge retention time, Chem. Eng. J., 181 (2012) 132-143.

[21] Hacıfazlığlu M.C., Tomasini H.R., Kabay N., Bertin L., Pek T., Kitiş M., Yiğit N., Yüksel M., Effect of pressure on desalination of MBR effluents with high salinity by using NF and RO processes for reuse in irrigation, J. Water Process Eng., 25 (2018) 22-27.

[22] Insel G., Karagunduz A., Aksel M., Cokgor E., Kor-Bicakci G., Ozyildiz G., Toroz I., Keskinler B., Membrane integrated process for advances treatment of high strength opium alkalois wastewaters, Wat. Sci.Technol., 77(7) (2018) 1899-1908. 